\title{
Economically viable efficient synthesis of $( \pm)$-methysticin: a component in kava potentially responsible for its cancer chemopreventive activity
}

\author{
Ahmad Ali Shaik, ${ }^{\text {a,b }}$ Jonathan Tan, ${ }^{\text {a Junxuan Lü }}{ }^{\text {a,b }}{ }^{\dagger}$ and Chengguo Xing ${ }^{a^{*}}$ \\ ${ }^{a}$ Department of Medicinal Chemistry, College of Pharmacy, University of Minnesota, 308 \\ Harvard St SE, Minneapolis, MN 554555, USA. \\ ${ }^{b}$ The Hormel Institute, University of Minnesota, 801 16th Avenue NE, Austin, MN 55912, USA. \\ ${ }^{\dagger}$ Present Address: Department of Biomedical Sciences, TTUHSC School of Pharmacy, $1300 \mathrm{~S}$. \\ Coulter, Amarillo, TX 79106, USA. \\ E-mail: xingx009@umn.edu
}

\begin{abstract}
A highly efficient and green synthesis of $( \pm)$-methysticin was developed from inexpensive piperonal, requiring two extraction procedures and one chromatographic purification in the final step with $51 \%$ overall yield. This new method is superior compared to known literature procedures and is highly reproducible and scalable up to gram scale.
\end{abstract}

Keywords: Methysticin, kava, kavalactones, NF- $\mathrm{B}$ inhibitory activity, aldol condensation, lactonization

\section{Introduction}

Kava or kava kava is an extract of the roots of a kava plant (Piper methysticum), which grows widely in the Hawaii, South Pacific islands including Vanuatu and Fiji. ${ }^{1}$ Aqueous extract of kava root has been consumed in this region as an apparently safe beverage and also used as a folk medicine for centuries. ${ }^{2,3}$ Kava and its constituents possess significant biological activities including analgesic, ${ }^{4}$ anesthetic, antifungal, antithrombotic, ${ }^{5}$ anticonvulsive, ${ }^{6}$ and musclerelaxant $^{7}$. Furthermore, Steiner's research findings revealed that kava consumption had an inverse correlation to cancer incidence rates. ${ }^{8}$ These attractive properties of kava have caught the attention of many researchers in both academic and pharmaceutical research sectors.

Two kava preparation methods are popular, among which traditional kava is prepared as an aqueous extract of kava root while those most commonly used in the Western countries are prepared as organic extracts (mainly ethanol or acetone). As of 2000, kava was the ninth most popular herbal product in the US in terms of global sale. ${ }^{9}$ Due to some controversial 
idiosyncratic hepatotoxic potentially derived from kava usage, ${ }^{10-13}$ the Food and Drug Administration (FDA) issued a warning on usage of commercial kava and kava containing dietary supplements in 2002. The chemical components underlying the various bioactivities and potential toxicity are not completely understood.

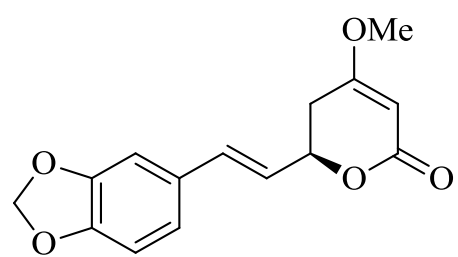

(+)-Methysticin 1

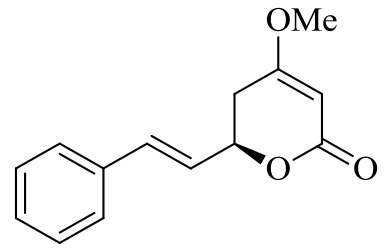

$(+)$-Kavain 3

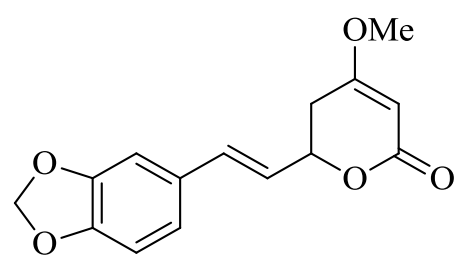

$( \pm)$-Methysticin 1

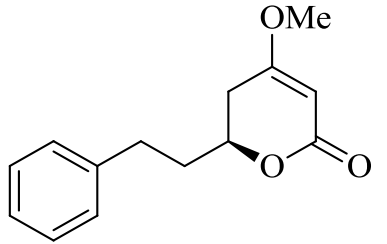

(+)-Dihydrokavain 4

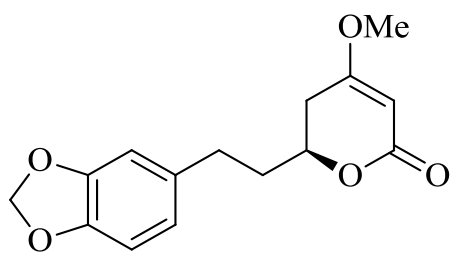

(+)-Dihydromethysticin 2

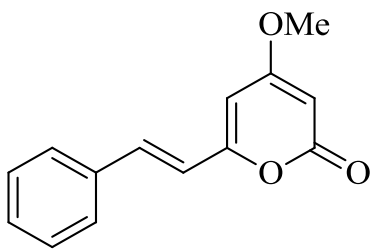

Desmethoxyyangonin 5

Figure 1. Structures of representative kavalactones.

The chemical constituents of Piper methysticum has been extensively studied and found to contain predominantly natural products from a number of phytochemical groups including kavalactones and chalcones (flavokavains). ${ }^{14-17}$ Among the isolated compounds, kavalactones were identified as the active constituents responsible for its pharmacological activity. ${ }^{3,18}$ Representative major kavalactones are shown in Figure 1.

Recently we have demonstrated that kava has chemopreventive efficacy against lung cancer. ${ }^{19}$ In addition we also successfully identified that methysticin, a kavalactone suppresses $\mathrm{NF}-\kappa \mathrm{B}$ activation in lung cancer cell line. ${ }^{20}$ It's noteworthy that $(+)$-methysticin and synthetic $( \pm)$-methysticin 1 both have shown the same luciferase based NF- $\kappa$ B inhibitory activity $(0.58 \pm$ $0.18 \mu \mathrm{M})$. Encouraged with these research findings, we were interested in evaluating the in vivo efficacy of $( \pm)$-methysticin 1. In order to study the in vivo efficacy, we would need large quantities (about 50 grams) of methysticin. Although mixtures of kavalactones are readily available from kava extracts, the natural abundance of methysticin is low relative to other kavalactones and isolation of large quantities is challenging that involves multiple chromatographic purification. Till date there have been several synthetic methods reported in the literature for the synthesis of kavalctones, ${ }^{21}$ which may be applicable for the synthesis of methysticin. But the substituents on aromatic ring may have influence on the reaction rates as well as overall yields. Most of the literature procedures specific for the synthesis methysticin are limited to milligrams scale. ${ }^{22}$ Moreover, these synthetic routes require chromatographic purification in each step and often with low overall yields. Such, are not economically viable 
large-scale preparation; some examples are show in Table $1 .{ }^{22}$ Most importantly many of these synthetic procedures involve transition metal catalyzed reactions $(\mathrm{Pd})$, requiring removal of trace metal residue from the final product, which again is not environmental friendly, involves additional procedures, ${ }^{23}$ and introduces potential risks of heavy metal-based adverse side effect. Taking account of these demerits, herein we have developed a short and highly reproducible synthesis of ( \pm )-methysticin 1 with good overall yields involving just two extractions, one final column purification, and no heavy metals.

Table 1. Literature procedures for the synthesis of methysticin and their overall yields

\begin{tabular}{|c|c|c|c|c|c|}
\hline Publication & Enantiopure/Racemic & $\begin{array}{l}\text { Total No. } \\
\text { of steps }\end{array}$ & $\begin{array}{c}\text { Overall } \\
\text { yield }(\%)^{\mathrm{b}}\end{array}$ & $\begin{array}{c}\text { No. of } \\
\text { purification } \\
\text { steps }\end{array}$ & $\begin{array}{c}\text { Metal } \\
\text { catalyst } \\
\text { used }\end{array}$ \\
\hline $\begin{array}{c}\text { Organic Lett. } \\
\text { 2009, } 11 \\
3642 .\end{array}$ & Racemic & 4 & 30.7 & 2 & $\mathrm{Pd}$ \\
\hline $\begin{array}{c}\text { Tetrahedron } \\
\text { Lett. 2008, } \\
\text { 49, } 6607 .\end{array}$ & Racemic & 3 & 20.8 & 2 & $\mathrm{Pd}$ \\
\hline $\begin{array}{c}\text { Organic Lett. } \\
\mathbf{2 0 0 4 , 6}, \\
2317 .\end{array}$ & Enantiopure & 7 & 24 & 6 & $\mathrm{Sn}, \mathrm{Pd}$ \\
\hline
\end{tabular}

${ }^{a}$ Including steps involved in the synthesis of non-commercial substrates. ${ }^{b}$ Overall yield includes yields of non-commercial substrates used in the synthesis.

\section{Results and Discussion}

Our initial attempt focused on the synthesis of $(E)-3,4-$ Methylenedioxycinnamaldehyde. We first attempted the Wittig reaction of piperonal 6 with ylide 7 as shown in Scheme 1. Low yields of (E)-3,4-Methylenedioxycinnamaldehyde were obtained when the reaction was carried out with stoichiometric amounts of piperonal 6 and ylide 7, with considerable amount of 5-(1,3benzodioxol-5yl)-2E,4E-pentadienal 9 being isolated as the major byproduct. The 5-(1,3benzodioxol-5yl)-2E,4E-pentadienal $9,{ }^{28}$ had a very close $R f$ values on TLC with $(E)-3,4-$ Methylenedioxycinnamaldehyde $\mathbf{8}$ and piperonal $\mathbf{6}$ making chromatographic purification challenging to obtain pure $(E)$-3,4-Methylenedioxycinnamaldehyde $\mathbf{8}$. Therefore two equivalents of piperonal 6 were used with respect to ylide 7 to minimize the formation of the byproduct. The conversion was lower in addition to small amounts of 5-(1,3-benzodioxol-5yl)-2E,4Epentadienal 9 formation. Based on these two attempts we decided this method was not appropriate for large scale preparation of (E)-3,4-Methylenedioxycinnamaldehyde. 


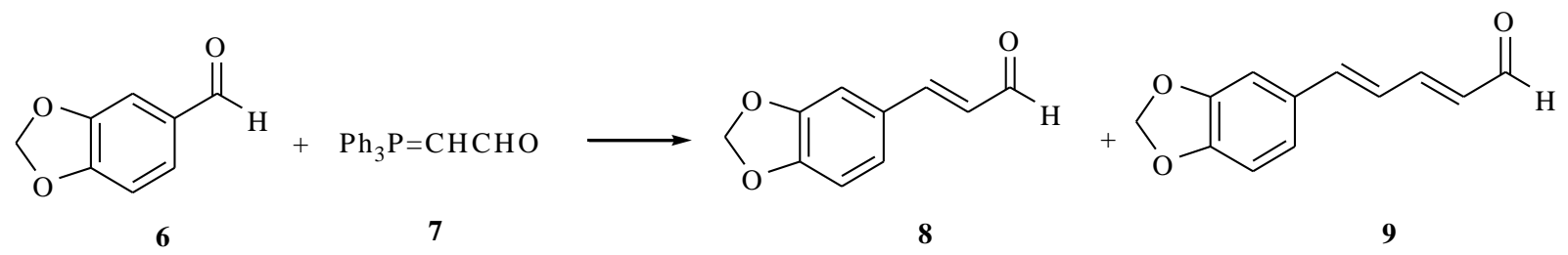

Scheme 1. Synthesis of compound 8 by Wittig olefination. Conditions: toluene, $95{ }^{\circ} \mathrm{C}$.

An alternative highly efficient one-pot procedure (Scheme 2) was adopted to synthesize (E)3,4-methylenedioxycinnamaldehyde, involving (1,3-dioxolan-2-yl)methyl triphenylphosphonium bromide 10, which was synthesized based on known literature procedures in quantitative yields $(98 \%){ }^{24}$ The ylide was generated in situ from (1,3-dioxolan-2-yl)methyl triphenylphosphonium bromide 10 using Lithium methoxide followed by reaction with piperonal $\mathbf{6}$ in dry THF to yield the intermediate 11, which upon treatment with $1 N \mathrm{HCl}$ in the same pot to yield crude $(E)-3,4-$ Methylenedioxycinnamaldehyde 8. Importantly byproduct $\mathbf{9}$ formation was not observed by employing this new improved protocol. Moreover no further purification was required at this stage, making this a superior method compared to Scheme 1.

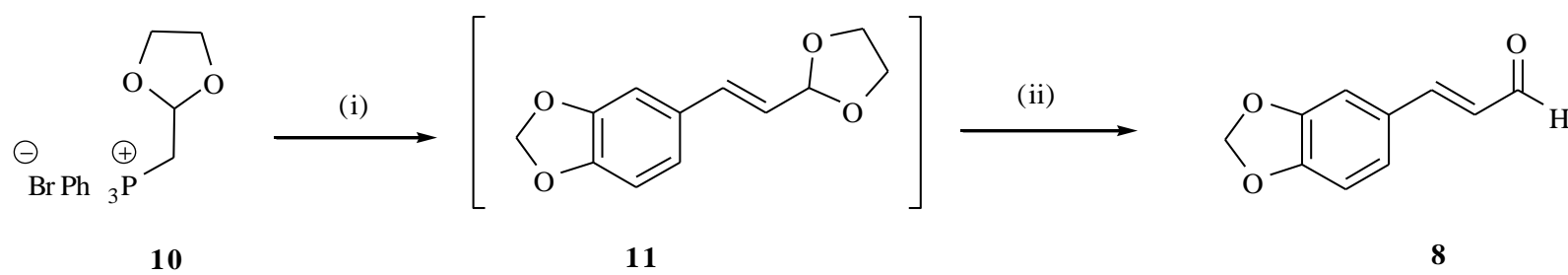

Scheme 2. One-pot synthesis of compound 8. Reagents and conditions: (i) LiOMe, dry THF, $0{ }^{0} \mathrm{C}$, Piperonal 6, $70{ }^{\circ} \mathrm{C}$; (ii) $1 \mathrm{~N} \mathrm{HCl}$, THF.

In the second step, aldol condensation of (E)-3,4-methylenedioxycinnamaldehyde $\mathbf{8}$ and the dianion of ethylacetoacetate, which was generated from ethylacetoacetate 12 upon treatment with $\mathrm{NaH}$ and $n$-BuLi, yielded the aldol adduct $\delta$-hydroxy- $\beta$-ketoester 13. Lactonization of $\delta$ hydroxy- $\beta$-ketoester was carried out under mild basic conditions using anhydrous $\mathrm{K}_{2} \mathrm{CO}_{3}$ in methanol. ${ }^{22 \mathrm{c}}$ Instead of isolating $\beta$-keto lactone intermediate, we were able to simply remove the methanol and carry out methyl ether formation using dimethylsulfate in acetone in the same pot to afford ( \pm )-methysticin 1 (Scheme 3). In order to validate reproducibility of this method, the same experiment was carried out multiple times with scales ranging from milligrams to grams and the overall yields range from 48.6-52.3\%. We also found that purification of intermediates 8 and $\mathbf{1 3}$ do not improve the overall yield. 


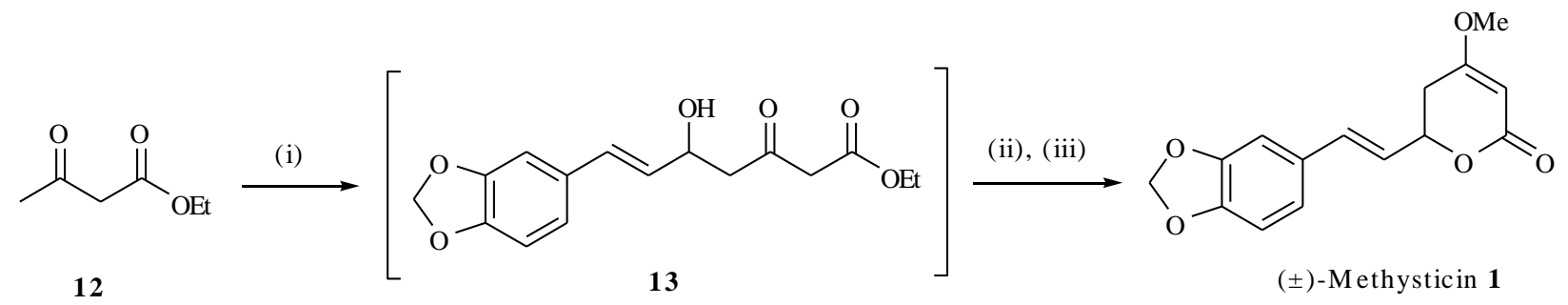

Scheme 3. Synthesis of ( \pm )-methysticin 1. Reagents and conditions: (i) NaH, $n$-BuLi, dry THF, $0{ }^{\circ} \mathrm{C}$, compound 8, $-55{ }^{\circ} \mathrm{C}$; (ii) Anhy. $\mathrm{K}_{2} \mathrm{CO}_{3}$, methanol; (iii) $\mathrm{Me}_{2} \mathrm{SO}_{4}$, acetone.

In order to further simplify the synthesis, we attempted one pot synthesis for the second step; by excluding the extraction of aldol adduct $\delta$-hydroxy- $\beta$-ketoester 13 . In order to accomplish this, the reaction mixture of the aldol adduct 13 was quenched with methanol and lactonization was carried out followed by methyl ether formation in one pot. In this case even though the reaction was carried out under similar reaction conditions we didn't observe the formation of methysticin. Instead, several non-polar spots were observed on TLC upon final workup. It was unclear why the reaction did not proceed as expected and we speculate that the byproducts formed upon quenching with methanol and traces of triphenylphosphine oxide remaining from step I may be influencing the lactonization and methyl ether formation. In order to confirm the reaction was proceeding through the aldol adduct $\delta$-hydroxy- $\beta$-ketoester $\mathbf{1 3}$, we purified the intermediate and complete characterization data were furnished in the experimental section. (E)-3,4-methylenedioxycinnamaldehyde characterization data was in agreement with previous literature reported values. ${ }^{24-28}$

\section{Conclusions}

In summary, we developed a highly efficient and reproducible gram scale preparation of $( \pm)$ methysticin starting with commercially available piperonal. This current strategy was very advantageous when compared with known literature procedures. This new synthesis involves four steps, two extractions, one chromatographic purification, is free from toxic metal catalyzed reactions, and has a very high overall yield that is easily scalable. Further in vivo efficacy study of methysticin is underway in our laboratory.

\section{Experimental Section}

General. All commercial reagents and anhydrous solvents were purchased from vendors and were used without further purification or distillation, unless otherwise stated. All non-aqueous reactions were carried out under an atmosphere of dry nitrogen in dried glassware. Analytical 
thin layer chromatography (TLC) was performed on EM Science silica gel $60 \mathrm{~F}_{254}(0.25 \mathrm{~mm})$. Compounds were visualized by UV light and further stained with $p$-anisaldehyde solutions followed by heating. Flash column chromatography was performed on Whatman Inc. silica gel (230-400 mesh). The ${ }^{1} \mathrm{H}$ NMR and ${ }^{13} \mathrm{C}$ NMR spectra were recorded on a Bruker Advance 400 $\mathrm{MHz}$ spectrometer. The chemical shifts for ${ }^{1} \mathrm{H}$ NMR are reported in ppm downfield to $\mathrm{CDCl}_{3}$ (7.26 ppm), coupling constants were in Hz. ESI mode mass spectra were recorded on a Bruker BiotofII mass spectrometer.

\section{Procedure for the linear synthesis of methysticin:}

Step I. Synthesis of (E)-3,4-Methylenedioxycinnamaldehyde (8). Lithium methoxide (19.8 $\mathrm{mmol}$ ) in methanol was added dropwise to a solution of (1,3-dioxolan-2-yl)methyl triphenylphosphonium bromide $10(19.8 \mathrm{mmol})$ in dry THF under nitrogen atmosphere at $0{ }^{\circ} \mathrm{C}$ and stirred at same temperature for $30 \mathrm{~min}$. Piperonal $6(13.2 \mathrm{mmol})$ in dry THF was added dropwise to the reaction mixture and further stirred for another $30 \mathrm{~min}$. The reaction mixture was brought up to room temperature and stirred at $70{ }^{\circ} \mathrm{C}$ for 6 hours. Reaction progress was monitored by TLC. Upon complete consumption of piperonal, reaction mixture was brought down to $0{ }^{\circ} \mathrm{C}$ and added $1 N \mathrm{HCl}(40 \mathrm{~mL})$. After stirring at room temperature for 3 hours reaction mixture was diluted with water and extracted with ethylacetate $(2 \times 40 \mathrm{~mL})$. Organic layers were combined, washed with saturated $\mathrm{NaCl}$ solution and dried over anhydrous $\mathrm{MgSO}_{4}$. The solvent was evaporated in vacuo and the residue was dried under high vacuum for overnight, to yield (E)-3,4-methylenedioxycinnamaldehyde 8, which was taken to step II without purification.

Step II: Synthesis of ( \pm -Methysticin 1. Ethylacetoacetate $12(13.9 \mathrm{mmol})$ was added dropwise to a slurry of sodium hydride $(26.4 \mathrm{mmol})$ in dry THF under nitrogen atmosphere at $0{ }^{\circ} \mathrm{C}$ and stirred at same temperature for $30 \mathrm{~min}$. Then $n$ - BuLi $(26.4 \mathrm{mmol})$ was added drop wise over a period of $10 \mathrm{~min}$ and further stirred for another $30 \mathrm{~min}$ at $0{ }^{\circ} \mathrm{C}$. The reaction mixture was brought down to $-55{ }^{\circ} \mathrm{C}$, when $(E)-3,4$-methylenedioxycinnamaldehyde 8 (13.9 mmol in dry THF) was added dropwise. After 30 min reaction mixture was brought up to room temperature and stirred further for 4-5 hours. Reaction mixture was quenched with saturated aqueous ammonium chloride solution upon completion of starting materials as judged by TLC and extracted with ethyl acetate $(2 \times 60 \mathrm{~mL})$. Organic layers were combined, washed with saturated $\mathrm{NaCl}$ solution and dried over anhydrous $\mathrm{MgSO}_{4}$. The solvent was evaporated in vacuo to yield aldol adduct $\delta$ hydroxy- $\beta$-ketoester 13. Anhydrous $\mathrm{K}_{2} \mathrm{CO}_{3}(27.8 \mathrm{mmol})$ was added to the aldol adduct $\delta$ hydroxy- $\beta$-ketoester 13 in methanol at room temperature and stirred for 2 hours. Upon reaction completion, methanol was removed under reduced pressure and the reaction mass was redissolved in anhydrous acetone followed by addition of dimethylsulfate $(27.8 \mathrm{mmol})$. The reaction mixture was stirred at room temperature for overnight and diluted with ethyl acetate; organic layer was washed with $1 N \mathrm{HCl}$ and dried over anhydrous $\mathrm{MgSO}_{4}$. Ethyl acetate was evaporated in vacuo and the residue was purified by flash column chromatography on silica gel to give pure methysticin $\mathbf{1}$. 
(士)-Methysticin (1): ${ }^{22}$ Yield: 51\%, TLC (EtOAc:Hexane = 1:1) Rf 0.34, colourless solid, ${ }^{1} \mathrm{H}$ NMR (400 MHz, CDCl $\left.)_{3}\right): \delta .85(1 \mathrm{H}, \mathrm{d}, J 1.4 \mathrm{~Hz}, \mathrm{Ar}-), 6.76(1 \mathrm{H}, \mathrm{dd}, J$ 8.0, $1.4 \mathrm{~Hz}, \mathrm{Ar}-), 6.69$ $(1 \mathrm{H}, \mathrm{d}, J 8.0 \mathrm{~Hz}, \mathrm{Ar}-), 6.56(1 \mathrm{H}, \mathrm{d}, J 15.8 \mathrm{~Hz}, \mathrm{Ar}-\mathrm{CH}=\mathrm{CH}-), 6.01(1 \mathrm{H}, \mathrm{dd}, J 15.9,6.3 \mathrm{~Hz}, \mathrm{Ar}-$ $\mathrm{CH}=\mathrm{CH}-), 5.89\left(2 \mathrm{H}, \mathrm{s},-\mathrm{OCH} \mathbf{H}_{2} \mathrm{O}-\right), 5.12(1 \mathrm{H}, \mathrm{d}, J 1.3 \mathrm{~Hz},-\mathrm{C}(=\mathrm{O})-\mathrm{CH}=\mathrm{C}-), 4.91-4.98(1 \mathrm{H}, \mathrm{m},-$ $\left.\mathrm{O}-\mathrm{CH}(\mathrm{CH}=)-\mathrm{CH}_{2}\right), 3.69\left(3 \mathrm{H}, \mathrm{s},-\mathrm{OCH}_{3}\right), 2.58\left(1 \mathrm{H}, \mathrm{ddd}, J 17.0,10.9,1.4 \mathrm{~Hz},=\mathrm{C}\left(-\mathrm{OCH}_{3}\right)-\mathrm{CH}_{2^{-}}\right)$, $2.45\left(1 \mathrm{H}, \mathrm{dd}, J 17.1,4.4 \mathrm{~Hz},=\mathrm{C}\left(-\mathrm{OCH}_{3}\right)-\mathrm{CH}_{2}-\right) ;{ }^{13} \mathrm{C} \mathrm{NMR}\left(100 \mathrm{MHz}, \mathrm{CDCl}_{3}\right): \delta 172.3,166.7$, 148.1, 147.8, 132.9, 130.1, 123.6, 121.7, 108.3, 105.8, 101.2, 90.57, 75.9, 56.0, 33.4; ESI-MS (positive): $m / z, 297(\mathrm{M}+\mathrm{Na})^{+}$

(E)-Ethyl 7-(benzo[d][1,3]dioxol-5-yl)-5-hydroxy-3-oxohept-6-enoate (Aldol adduct-13): TLC (EtOAc:Hexane = 1:1) $R f 0.42$, Pale yellow liquid, ${ }^{1} \mathrm{H}$ NMR $\left(400 \mathrm{MHz}, \mathrm{CDCl}_{3}\right): \delta 6.87(1 \mathrm{H}, \mathrm{d}, J$ $1.5 \mathrm{~Hz}, \mathrm{Ar}-), 6.77(1 \mathrm{H}, \mathrm{dd}, J$ 8.0, $1.5 \mathrm{~Hz}, \mathrm{Ar}-), 6.71(1 \mathrm{H}, \mathrm{d}, J 8.0 \mathrm{~Hz}, \mathrm{Ar}-), 6.52(1 \mathrm{H}, \mathrm{d}, J 15.8$ $\mathrm{Hz}, \mathrm{Ar}-\mathrm{CH}=\mathrm{CH}-), 6.01$ (1H, dd, $J$ 15.8, 6.2 Hz, Ar-CH=CH-), $5.92\left(2 \mathrm{H}, \mathrm{s},-\mathrm{OCH}_{2} \mathrm{O}-\right)$, 4.78-4.66 $\left(1 \mathrm{H}, \mathrm{m},=\mathrm{CH}-\mathrm{CH}(\mathrm{OH})-\mathrm{CH}_{2}-\right), 4.17\left(2 \mathrm{H}, \mathrm{q}, J 7.2 \mathrm{~Hz}, \mathrm{C}(=\mathrm{O})-\mathrm{OCH}_{2}-\mathrm{CH}_{3}\right) 3.48(2 \mathrm{H}, \mathrm{s}, \mathrm{C}(=\mathrm{O})-$ $\left.\mathrm{CH}_{2}-\mathrm{COOCH}_{2} \mathrm{CH}_{3}\right), \quad 2.84-2.80\left(2 \mathrm{H}, \quad \mathrm{m}, \quad \mathrm{CH}(\mathrm{OH})-\mathrm{CH}_{2}-\mathrm{C}=\mathrm{O}\right), \quad 1.25 \quad(3 \mathrm{H}, \quad \mathrm{t}, \quad J \quad 7.2 \mathrm{~Hz},-$ $\left.\mathrm{COOCH}_{2} \mathrm{CH}_{3}\right) ;{ }^{13} \mathrm{C}$ NMR $\left(100 \mathrm{MHz}, \mathrm{CDCl}_{3}\right): \delta 203.0,167.2,148.3,147.7,131.1,130.8,128.3$, 121.3, 108.6, 106.0, 101.4, 68.7, 61.9, 50.3, 49.9, 14.4 ; ESI-MS (positive): $\mathrm{m} / \mathrm{z} 329(\mathrm{M}+\mathrm{Na})^{+}$

\section{Acknowledgements}

This investigation was supported by Grants R03CA125844 and R01CA142649 from National Cancer Institute, NIH (C. Xing).

\section{References}

1. For a review, see: Lebot, V.; Merlin, M.; Lindstrom, L. KaVa-the Pacific Elixir: The Definitive Guide to its Ethnobotony, History, and Chemistry; Healing Arts Press: Rochester, VT, 1997.

2. Norton, S. A.; Ruze, P. J. Am. Acad. Dermatol. 1994, 31, 89-97.

3. Singh, Y. N., Singh, N. N. CNS Drugs 2002, 16, 731-743.

4. (a) Jamieson, D. D.; Duffield, P. H. Clin. Exp. Pharmacol. Physiol. 1990, 17, 495. (b) Wu, D.; Yu, L.; Nair, M. G.; DeWitt, D. L.; Ramsewak, R. S. Phytomedicine 2002, 9, 41.

5. Gleitz, J.; Beile, A.; Wilkens, P.; Ameri, A.; Peters, T. Planta Med. 1997, 63, 27.

6. Schmitz, D.; Zhang, C. L.; Chatterjee, S. S.; Heinemann, U. Arch. Pharmacol. Toxicol. 1995, 351, 348 .

7. Seitz, U.; Amerl, A.; Pelzer, H.; Gleitz, J.; Peters, T. Planta Med. 1997, 63, 303.

8. Steiner, G. G. Hawaii Med. J. 2000, 59, 420.

9. Blumenthal, M.; Goldberg, A.; Brinckmann, J. Herbal Medicine: Expanded Commission E monographs, 2000, 233. 
10. Clayton, N. P.; Yoshizawa, K.; Kissling, G. E.; Burka, L. T.; Chan, P. C.; Nyska, A. Exp. Toxicol. Pathol. 2007, 58, 223.

11. Teschke, R.; Schwarzenboeck, A.; Hennermann, K. H. Eur. J. Gastroenterol. Hepatol. 2008, 20, 1182 .

12. Yamazaki, Y.; Hashida, H.; Arita, A.; Hamaguchi, K.; Shimura, F. Food Chem.Toxicol. 2008, 46, 3732.

13. Ernst, E. Br. J. Clin. Pharmacol. 2007, 64, 415.

14. Bobeldijk, I.; Boonzaaijer, G.; Spies-Faber, E. J.; Vaes, W. H. J. Chromatogr., A. 2005, 1067, 107.

15. Dharmaratne, H. R.; Nanayakkara, N. P.; Khan, I. A. Phytochemistry 2002, 59, 429.

16. Johnson, B. M.; Qiu, S. X.; Zhang, S.; Zhang, F.; Burdette, J. E.; Yu, L.; Bolton, J. L.; Vanbreemen, R. B. Chem. Res. Toxicol. 2003, 16, 733.

17. Parmar, V. S.; Jain, S. C.; Bisht, K. S.; Jain, R.; Taneja, P.; Jha, A.; Tyagi, O. D.; Prasad, A. K.; Wengel, J.; Olsen, C. E.; Boll, P. M. Phytochemistry 1997, 64, 597.

18. Bilia, A. R.; Gallori, S.; Vincieri, F. F. Life Sci. 2002, 70, 2581.

19. Johnson, T. E.; Kassie, F.; O’Sullivan, M. G.; Negia, M.; Hanson, T. E.; Upadhyaya, P.; Ruvolo, P. P.; Hecht, S. S.; Xing, C. Cancer Prevent. Res. 2008, 1, 430.

20. Shaik, A. A.; Hermanson, D. L.; Xing, C. Bio. Org. Med. Lett. 2009,19, 5732.

21. (a) Kostermans, D. Nature 1950, 166, 788. (b) Piantosi, C.; Skulason, V. G. J. Pharm. Sci. 1964, 53, 902. (c) Izawa, T.; Mukaiyama, T. Chem. Lett. 1975, 161.; (d) Israili, Z. H.; Smissman, E. E. J. Org. Chem. 1976, 41, 4070. (e) Rosen, J. D.; Nelson, T. D.; Huffman, M. A.; McNamara, J. M. Tetrahedron Lett. 2003, 44, 365. (f) Pierres, C.; George, P.; Hijfte, L. V.; Ducep, J.-B.; Hibert, M.; Mann, A. Tetrahedron Lett. 2003, 44, 3645. (g) Castellino, S.; Sims, J. Tetrahedron Lett. 1984, 25, 4059. (h) Spino, C.; Mayes, N.; Desfossés, H. Tetrahedron Lett. 1996, 37, 6503. (i) Du, H.; Zhai, D.; Ding, K. Chem. Eur. J. 2004, 10, 5964. (j) Xang, D.-F. ; Yue, M.-J. Synlett 2005, 2077. (k) Sabitha, G.; Sudhakar, K.; Yadav, J. S. Tetrahedron Lett. 2006, 47, 8599. (1) Kamal, A.; Krishnaji, T.; Khanna, G. B. R. Tetrahedron Lett. 2006, 47, 8657. (m) Villano, R.; Acocella, M. R.; Massa, A.; Palombi, L.; Scettri, A. Tetrahedron: Asymmetry. 2006, 17, 3332. (n) Lin, L.; Chen, Z.; Yang, X.; Liu, X.; Feng, X. Org. Lett. 2008, 10, 1311.

22. (a) Moro, A. V.; Cardoso, F. S. P.; Correia, C. R. D. Org. Lett. 2009, 11, 3642. (b) Amaral, P. A.; Gouault, N.; Roch, M. L.; Eifler-Lima, V. L.; David, M. Tetrahedron Lett. 2008, 49, 6607. (c) Smith, T. E.; Djang, M.; Velander, A. J.; Downey, C. W.; Carroll, K. A.; Alpeh, S. Org. Lett. 2004, 14, 2317.

23. (a) Huang, J-P.; Chen, X-X.; Gu, S-X.; Zhao, L.; Chen., W. X.; Chen, F-E. Org. Process Res. Dev., 2010, 14, 939. (b) Garrett, C. E.; Prasad, K. Adv. Synth. Catal. 2004, 346, 889. (c) Pink, C. J.; Wong, H.; Ferreira, F. C.; Livingston, A. G. Org. Process Res. Dev. 2008, 12, 589. (d) Chen, C. Y.; Dagneau, P.; Grabowski, E. J. J.; Oballa, R.; O’Shea, P.; Prasit, P.; Robichaud, J.; Tillyer, R.; Wang, X. J. Org. Chem. 2003, 68, 2633. (e) Bullock, K. M.; 
Mitchell, M. B.; Toczko, J. F. Org. Process Res. Dev. 2008, 12, 896. (f) Urawa, Y.; Miyazawa, M.; Ozeki, N.; Ogura, K. Org. Process Res. Dev. 2003, 7, 191.

24. Cresp, T. M.; Sargent, M. V.; Vogel, P. J.C.S. Perkin trans. I, 1974, 37.

25. Leung, P. S-W.; Teng, Y.; Toy, P. H. Org. Lett. 2010, 12, 4996.

26. Schobert, R.; Siegfried, S.; Gordon, G. J. J. C. S. Perkin trans. I 2001, 2393.

27. Joshi, B. P.; Sharma, A.; Sinha, A. K. Tetrahedron Lett. 2005, 61, 3075.

28. Chandrasekhar, S.; Reddy, M. V.; Reddy, K. S.; Ramarao, C. Tetrahedron Lett. 2000, 41, 2667. 